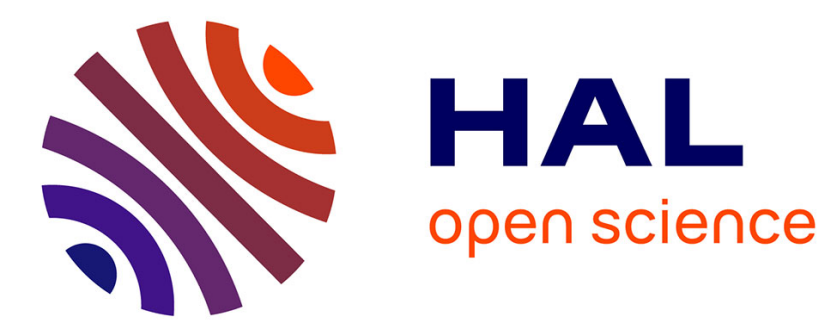

\title{
A large crocodyloid from the Oligocene of the Bugti Hills, Pakistan
}

\author{
Jérémy Martin, Pierre-Olivier Antoine, Vincent Perrier, Jean-Loup \\ Welcomme, Grégoire Metais, Laurent Marivaux
}

\section{- To cite this version:}

Jérémy Martin, Pierre-Olivier Antoine, Vincent Perrier, Jean-Loup Welcomme, Grégoire Metais, et al.. A large crocodyloid from the Oligocene of the Bugti Hills, Pakistan. Journal of Vertebrate Paleontology, 2019, 39 (4), pp.e1671427. 10.1080/02724634.2019.1671427 . hal-02376991

\section{HAL Id: hal-02376991 \\ https://hal.science/hal-02376991}

Submitted on 9 May 2020

HAL is a multi-disciplinary open access archive for the deposit and dissemination of scientific research documents, whether they are published or not. The documents may come from teaching and research institutions in France or abroad, or from public or private research centers.
L'archive ouverte pluridisciplinaire HAL, est destinée au dépôt et à la diffusion de documents scientifiques de niveau recherche, publiés ou non, émanant des établissements d'enseignement et de recherche français ou étrangers, des laboratoires publics ou privés. 
A large crocodyloid from the Oligocene of the Bugti Hills, Pakistan

JEREMY E. MARTIN, ${ }^{1, *}$ PIERRE-OLIVIER ANTOINE, ${ }^{2}$ VINCENT PERRIER, ${ }^{1}$ JEANLOUP WELCOMME, ${ }^{3}$ GREGOIRE METAIS,${ }^{4}$ and LAURENT MARIVAUX ${ }^{2} ;{ }^{1}$ Univ. Lyon, ENS de Lyon, Université Claude Bernard Lyon 1, CNRS, UMR 5276 Laboratoire de Géologie de Lyon: Terre, Planètes, Environnement, F-69342 46 Allée d'Italie, Lyon, France, jeremy.martin@ens-lyon.fr; ${ }^{2}$ Institut des Sciences de l'Evolution, UMR5554, CNRS, IRD, EPHE, Université de Montpellier, Montpellier, France; ${ }^{3} 10$ rue droite 34360 Saint-Chinian, France; ${ }^{4}$ Centre de Recherche sur la Paléobiodiversité et les Paléoenvironnements, UMR 7207 (CNRS, MNHN), Sorbonne Université, Muséum national d'Histoire naturelle, 8 rue Buffon 75005 Paris, France

*Corresponding author 
Cenozoic continental deposits of the Bugti Hills crop out South of the Sulaiman Range in Balochistan, Pakistan, and they have been renowned since Vickary (1846) for their exceptionally rich vertebrate-bearing Miocene localities. This led G.E. Pilgrim (Geological Survey of India) then C. Foster-Cooper (University of Cambridge) to conduct expeditions in the beginning of the $20^{\text {th }}$ century. More recent expeditions in the late 1990 s have reported the occurrence of successive fossiliferous horizons spanning the Eocene-Pleistocene interval (Welcomme et al., 1997, 2001; Welcomme and Ginsburg, 1997). Fossil-yielding series around Dera Bugti document marine, coastal, then fluvio-lacustrine depositional environments during the Eocene, the earliest Oligocene, and the late Oligocene-Pleistocene, respectively (Welcomme et al., 2001; Métais et al., 2009b; Roddaz et al., 2011; Antoine et al., 2013). The most species-rich intervals, at least for mammals, are Oligocene and Miocene in age (Marivaux et al., 1999, 2001, 2002a, 2002b, 2005; Antoine and Welcomme, 2000; Antoine et al., 2003, 2004, 2010, 2013; Métais et al., 2003, 2006, 2009a, 2017; Marivaux and Welcomme, 2003; Orliac et al., 2009, 2010). As for crocodylians, fossil remains were initially described from the Bugti Hills by Pilgrim $(1908,1912)$, but their precise stratigraphic provenance has not been recorded. Most of those fossils are quite fragmentary and they consist of large tomistomine skull fragments (Martin, 2018) formerly referred to species of Gavialis (Pilgrim, 1908, 1912). Together with these remains, Crocodilus bugtiensis Pilgrim, 1908 was erected from a left maxilla and associated skull fragments of remarkable size found at Pishi Nala. Since its formal description four years later (Pilgrim, 1912), the taxon has been briefly recorded from several levels in the Bugti Hills (Welcomme et al., 1997) but no detailed account has been given ever since. Here, we describe partial, yet diagnostic, mandibular elements of a large crocodyloid recovered from upper Oligocene deposits of the Bugti Hills, which are morphologically compatible with the skull elements described by Pilgrim (1912). This material was collected from a well-identified Oligocene horizon within 
the framework of the field campaigns that took place in Baluchistan between 1995 and 2000. We also report a partial mandible collected in the 1920s from Baluchistan but with no provenance data. Finally, we mention the presence of toothmarks on associated megaherbivore remains.

Institutional Abbreviations-IM, Indian Museum, Calcutta, India; NHMUK, Natural History Museum, London, United Kingdom; UM-DB-LC, Université de MontpellierDera Bugti, Lundo Chur locality.

\section{GEOLOGICAL SETTING}

Pilgrim (1912) states that the holotype specimen IM E221 comes from the lowest beds in the series in Pishi Nala, Bugti Hills. Unfortunately, this information remains ambiguous and depending on the occurrence and current understanding of the systematics of co-occurring ruminant mammals, one may consider its provenance as lower Oligocene or upper Oligocene-lower Miocene (Pilgrim, 1912; Antoine et al., 2013; Métais et al., 2017). For this reason, we consider IM E221 as Oligocene in age. On the other hand, the age and provenance of UM-DB-LCJ1-02 is clearer. This specimen was later collected in the Bugti Hills (Baluchistan, Pakistan) by the members of the "Mission Paléontologique Française au Baloutchistan" (MPFB), in deposits situated in the south of the Zin Anticline, Lundo Chur section, and upper Oligocene in age (see Welcomme et al., 2001; Antoine et al., 2003, 2004; Métais et al., 2009b; Orliac et al., 2010). UM-DB-LCJ1-02 originates from the J1 horizon (lower elephantoid-bearing horizon; Antoine et al., 2003, 2004) of the Lundo Chur section, about $25 \mathrm{~km}$ south of Dera Bugti (Welcomme et al., 2001; Métais et al., 2009b).

\section{SYSTEMATIC PALEONTOLOGY}


CROCODYLIA Gmelin, 1789

CROCODYLOIDEA Fitzinger, 1826

Family incertae sedis

ASTORGOSUCHUS, gen. nov.

Type species-Crocodilus bugtiensis Pilgrim, 1908

Diagnosis - As for the type and only known species

Etymology_From the Greek 'Astorgos' meaning merciless or inexorable; and 'souchos', from the Greek name of the crocodile-headed god in Egyptian mythology (Sobek); referring to the inexorable fate of animals being seized in such powerful jaws.

ASTORGOSUCHUS BUGTIENSIS, combinatio nova

(Figs. 1-4)

Holotype - IM E221, parts of a single cranium including a nearly complete left maxilla and connected fragments of a premaxilla, nasal and lacrimal (Pilgrim, 1912 and Fig. 1). Pilgrim (1912) reports this specimen as originating from Pishi Nala in the Bugti Hills.

Referred Material- UM-DB-LCJ1-02, a mandibular symphysis including the dentaries and splenials (Figs. 2, 3). NHMUK R.5266 (Fig. 4) was presented to NHMUK in 1925 by Clive Foster-Cooper and is labeled as originating from the Miocene of Baluchistan. However, its precise origin (locality) and age (horizon) remain unknown.

Locality and Horizon-Oligocene of the Bugti Hills, Baluchistan, Pakistan.

Diagnosis-Astorgosuchus bugtiensis is characterized by the following unique combination of skull characters as noted by Pilgrim (1912) (autapomorphies are denoted with *): total skull length larger than $80 \mathrm{~cm}$ for mature individuals; short-snouted skull as indicated by a rostrum only twice as long as wide; broad-headed skull as indicated by a rostrum at level 
of the largest maxillary alveolus as wide as the width in front of the orbits; largest maxillary alveolus is the fifth; presence of a deep notch lateral to the premaxillary-maxillary suture; presence of a deep notch located between the sixth and seventh maxillary alveoli for reception of the $11^{\text {th }}$ dentary tooth; enlarged external nares extending far posteriorly, almost reaching the level of the enlarged fifth maxillary alveolus*; nasals contributing to the external nares; presence of swollen and rugose prominences on the dorsal surface of the lacrimal (not contributing to the orbital margin)*, premaxilla and anterior part of the nasals. Astorgosuchus bugtiensis also displays a unique combination of mandibular characters among Crocodyloidea including: a mandibular symphysis encompassing the first seven dentary alveoli*; fused splenials penetrating in the mandibular rostrum to the level of the sixth dentary alveolus* and elevated contiguous large fourth and diminutive fifth dentary alveoli*. Differs from crocodylines, mekosuchines and the basal crocodyloid Asiatosuchus in having splenials involved in the mandibular symphysis; differs from tomistomines in having a shorter mandibular rostrum.

Description - The two newly reported specimens (NHMUK R.5266 and UM-DBLCJ1-02) comprise the fused right and left anterior portions of mandibular rami (Figs. 2-4). In NHMUK R.5266, the left mandibular ramus is preserved to the level of the ninth alveolus and the associated splenial is flanked on the entire preserved medial surface of the dentary ramus. However, the symphysial surface is somehow damaged and the extent to which the splenial contributes to it, is difficult to precisely ascertain (Fig. 4A-C). The relative dimensions and positions of dentary alveoli are identical to those of UM-DB-LCJ1-02. For those reasons, our description focuses on UM-DB-LCJ1-02.

UM-DB-LCJ1-02 preserves each dentary from the first to the seventh dentary alveoli. Several cracks run through the specimen, the anteriormost edge of the left dentary is slightly worn out, some of the ventral surface of the right dentary is eroded and teeth have been 
broken away with only roots remaining in some alveolar positions. The specimen has not undergone deformation and the left and right rami are symmetrical. The lateral surface of the dentary is profusely ornamented with deep circular foramina. They are sparsely distributed and slightly larger on the ventral surface.

The robust mandibular rostrum is slightly longer than wide, giving to it a general spoon-shape appearance when viewed dorsally (Figs. 2-3). Anterior to the largest alveoli, the outline of the rostrum forms an isosceles triangle in dorsal view, while the lateral margins behind the largest alveoli are parallel to each other. The dentaries meet medially from the level of the first to the fifth alveoli. As observed in occlusal view, the mandibular symphysis is strongly serrated and it forms a median ridge, which stops at the level of the adjoining anterior splenial processes. The splenials penetrate in the mandibular rostrum with the shape of an inverted Y-process, their anterior two-thirds running nearly parallel to the outer mandibular margin. Here, the occlusal surface of the splenials is faintly concave. The portion of the splenials contributing to the mandibular rostrum extends posteriorly to a point level the sixth and seventh dentary alveoli. The splenials do not contribute to the ventral surface of the mandible. As seen in posterior view, their dorsal margin forms a shelf in the mandibular rostrum. Below this shelf, the splenials enclose the small meckelian foramen, which opens posteroventrally (Fig. 3C, D).

Alveolar dimensions are presented in Table 1. All preserved dentary alveoli are nearly circular in outline (Figs 2A, B and 3A, B). The first alveolus is facing anterodorsally and seems to have hosted a procumbent tooth. The first right alveolus hosts a broken tooth root, which is markedly curved. The second alveolus is slightly smaller than the first one and is separated from it by less than a centimeter. It is also anterodorsally directed. A two-centimeter diastema separates the second from the third alveolus. The third alveolus opens on the anterior everted surface of the large fourth alveolus, both alveoli being contiguous but not 
confluent. The fourth alveolus is the largest of all preserved alveoli and it projects in a dorsolateral direction. Its lingual alveolar wall bulges along the occlusal surface of the mandibular rostrum. The fifth alveolus is much smaller and is also contiguous with the fourth alveolus, its dorsal margin protruding at the same level as the fourth alveolus. The sixth and seventh alveoli open at the level of the main occlusal surface of the dentary, and are about the same size. They are separated from each other with the seventh alveolus possessing a distinct outline along the lateral border of the dentary. Occlusal pits occur on the lateral margin of the dentary between the sixth and seventh alveoli. The medial margin of the dentary tooth row is pierced by numerous foramina of variable dimensions. The largest (about $13 \mathrm{~mm}$ in diameter) are observed at the level of the diastema between the second and third alveoli as well as medial to the fourth through sixth alveoli. A single tooth crown is preserved in the left third dentary alveolus of NHMUK R.5266 (Fig. 4). Despite a circular cross section, the crown is heavily worn and no feature of the enamel can be described.

\section{DISCUSSION}

Pilgrim $(1908,1912)$ was the first to describe and name several crocodylian species from the Bugti Hills, including a number of longirostrine forms (Martin, 2018). With these remains, Pilgrim (1908) erected Crocodilus bugtiensis, which was later described (Pilgrim, 1912) and represented by a portion of the rostrum (IM E221) from Pishi Nala near Dera Bugti. Although no overlapping material exists to relate the skull material described by Pilgrim (1912) with the mandibular material described above, we consider all these specimens to represent a single species for the following reasons: first, IM E 221, NHMUK R.5266 and UM-DBLCJ1-02 are all of large dimensions (i.e. skull length estimated over $80 \mathrm{~cm}$; Appendix 1) and all retain characters of the Crocodyloidea, as explained in the paragraph below. The skull (IM 
E221) as well as the two mandibles described here independently point to an animal with a remarkably broad cranium (Pilgrim, 1912; Appendix 1). The morphology of the maxillary and dentary tooth rows shares the same pattern of occlusion. Among crocodylians, at the level of the premaxillary-maxillary suture, a marked notch on the lateral margin of the rostrum always accommodate an enlarged dentary tooth of the anterior part of the lower jaw. Compatible with the deeply excavated premaxillary-maxillary notch, the mandibular specimens described herein show a distinctly enlarged fourth dentary tooth that was occluding at this level. Finally, the enlarged fifth maxillary tooth occludes laterally at the level of the sixth-seventh dentary alveoli, where an occlusal pit is well visible in NHMUK R.5266.

In light of these observations, we view all these three specimens as conspecific. The generic name 'Crocodilus' has traditionally been applied to a variety of fossil crocodylians with a "generalized non-alligatorid-like" morphology (Delfino et al., 2007). The new taxon from the Bugti Hills cannot be assigned to the genus Crocodylus or to any members of the Crocodylinae because of the significant posterior extent of the external nares and because its splenial is involved in the mandibular symphysis. For these reasons, we propose the name Astorgosuchus bugtiensis as a new combination for the Bugti crocodylian represented by IM E221, NHMUK R.5266 and UM-DB-LCJ1-02.

The fragmentary nature of Astorgosuchus bugtiensis does not facilitate a clear taxonomic attribution beyond Crocodyloidea. Although we did not examine the holotype firsthand, we view IM E221 as a large crocodyloid as evidenced by its enlarged fifth maxillary alveolus (Pilgrim, 1912, plate XXVI). The presence of an enlarged fourth dentary alveolus is plesiomorphic and observed in alligatorines, caimanines, and crocodyloids. The most notable character is the participation of the splenial in a relatively short, mandibular symphysis, which extends posteriorly to a point level with the seventh dentary alveoli. This character is not encountered in basal eusuchians or alligatoroids nor in any short-snouted 
basal eusuchians. On the contrary, deep splenial participation into the mandibular symphysis is observed in longirostrine forms, such as tomistomines and gavialids, where the mandibular symphysis is extensive and encompasses most of the mandibular length, a condition not approached in A. bugtiensis. In alligatoroids, the mandibular symphysis extends posteriorly at the level of the fourth dentary alveolus. In crocodyloids, the symphysis is slightly more elongate, extending posteriorly to a point level with the fifth alveolus. In some extinct crocodyloids such as species of the mekosuchine Kambara from Australia (Salisbury and Willis, 1996) or the basal crocodyloids 'Crocodilus' depressifrons from Europe (Delfino and Smith, 2009) and Asiatosuchus (Mook, 1940; Berg, 1966), the symphysis extends to the level of the sixth or seventh alveoli. In Kambara and ' $C$.' depressifrons, however, the splenials do not participate in the mandibular symphysis, although they approach it. Mook (1940, p. 2) describes the splenial in Asiatosuchus grangeri as almost approaching the symphysis but not actually doing so. The taxon most closely resembling Astorgosuchus bugtiensis is Asiatosuchus germanicus where the splenials are slightly involved in the symphysis (Berg, 1966, p.57), but admittedly, Astorgosuchus bugtiensis displays a stronger splenial involvement into the symphysis, reaching the sixth dentary alveoli. Although the precise placement of Astorgosuchus bugtiensis in a phylogenetic framework is beyond the scope of this study, we view Astorgosuchus bugtiensis as a probable basal crocodyloid close to Asiatosuchus germanicus in light of the following shared characters: mandibular symphysis extending to the level of the seventh alveolus; participation of the splenial into the mandibular symphysis; diastema between second and third alveoli and enlarged fourth alveolus. Astorgosuchus bugtiensis differs from Asiatosuchus germanicus in the relative dimensions of the fourth alveolus relative to the much smaller fifth dentary alveolus, and in its more extensive participation of the splenial in the mandibular symphysis. Astorgosuchus bugtiensis is recovered in much younger strata (Oligocene) than Asiatosuchus germanicus, which is 
Lutetian in age (i.e., middle Eocene). Although the affinities of the Asiatosuchus-like taxa remain unclear (Delfino and Smith, 2009), Astorgosuchus bugtiensis will require more complete specimens for its affinities to be assessed.

Total body length (TBL) of Astorgosuchus bugtiensis is estimated using mandibular width at the level of the largest dentary alveolus. A regression equation using skull and mandibular measurements of 13 individuals of the genus Crocodylus (Appendix 1) allowed to derive a skull length for $A$. bugtiensis of $80 \mathrm{~cm}$ for UM-DB-LCJ1-02 and of $91 \mathrm{~cm}$ for NHMUK R.5266. Measurements taken on a large series of Crocodylus porosus have demonstrated that the skull becomes shorter relative to the body length during ontogeny (Fukuda et al., 2013 and references therein). For this reason, the total length versus head length ratio (TL/HL) changes from 1:7 to well over 1:8 for $C$. porosus individuals with a skull length around $60 \mathrm{~cm}$ (Fukuda et al., 2013). Using a 1:8 ratio would result in a minimum TBL estimate for A. bugtiensis of 6.4 meters for UM-DB-LCJ1-02 and of 7.3 meters for NHMUK R.5266. A TL/HL of 1:8.8 was established for the longest $C$. porosus ever measured, which possesses a skull length of $70 \mathrm{~cm}$ (Britton et al., 2012), which is significantly smaller than the skull length estimated above for A. bugtiensis. Here, applying this ratio gives a TBL of 7 meters for UM-DB-LCJ1-02 and of 8 meters for NHMUK R.5266. Estimates should be taken with caution but one can reasonably consider probable that the largest representative of $A$. bugtiensis approached or surpassed 8 meters in TBL (Fig. S1).

The estimated size of adult $A$. bugtiensis falls in the range of other large fossil Crocodylus (Brochu and Storrs, 2012; Delfino and De Vos, 2014). The fossil record offers repeated instances of gigantism among semi-aquatic crocodylomorphs (Table 2), and based on cranial material, the largest exemplars could be estimated to surpass TBL of 10 meters (Head, 2001; Sereno et al., 2001; Aguilar et al., 2006; Riff and Aguilera, 2008). Astorgosuchus bugtiensis was retrieved in the same fluvio-lacustrine deposits as the large 
tomistomines 'Gavialis' curvirostris and 'Gavialis' breviceps (Pilgrim, 1908; 1912; Martin, 2018). Both of the later taxa co-occur with several megaherbivores, such as rhinocerotoids and chalicotheriids among perissodactyls, anthracotheriid artiodactyls and proboscideans (Antoine et al., 2003, 2004, 2013; Métais et al., 2009a; Lihoreau et al., 2017). Indeed, predator-prey interactions due to crocodylians are recorded on a wide array of mandibular and postcranial remains of rhinocerotoids, including the gigantic rhinocerotoid Paraceratherium bugtiense. The jaw of a juvenile specimen referred to as $P$. bugtiense has several large conical unhealed bisected tooth marks (Figure 5B) unambiguously left by a giant crocodylian (compare with Njau and Blumenschine, 2006), as for several postcranial remains of $P$. bugtiense, rhinocerotoids, and chalicotheriids (Figure 5), which would support the conspicuous nature of such predator-prey interactions at those times. Nevertheless, it is not possible to differentiate between tooth marks inflicted by A. bugtiensis or by other large tomistomines due to their similar tooth morphology. Presumably, these different crocodylians inhabited the same streams but did not share the same microhabitats as is possibly the case today in India with gharials and muggers (Da Silva and Lenin, 2010) or as previously discussed in various Mesozoic and Cenozoic aquatic habitats where both mesorostrine and longirostrine forms have been described (e.g. Salas-Gismondi et al., 2015; Martin et al., 2016; Souza et al., 2016). Whatever the predator-prey interactions, this ecosystem is remarkable for the gigantic sizes attained by several of its organisms calling for further investigation of the underlying evolutionary mechanisms accounting for increase in body size.

\section{ACKNOWLEDGMENTS}

JEM thanks L. Steel who provided all necessary support during his stay at NHMUK. This research received support from the SYNTHESYS Project http://www.synthesys.info/ which is 
financed by European Community Research Infrastructure Action under the FP7 Integrating Activities Programme (GB-TAF-4750 to JEM). We are very grateful to the late Nawab M. Akbar Khan Bugti, then Lord of the Bugti Tribes, and to all the members of the Bugti family, for their invitations, and their constant support. Warm thanks to H. E. Iqbal Akhund and K. Majidhula (Karachi) for their enthusiastic and continuous support. The authors are grateful to all other participants to the MPFB 1995-2004 field campaigns in Baluchistan. The fieldwork was supported by various funding institutions (CNRS, Université de Montpellier, ISE-M, Muséum National d'Histoire Naturelle in Paris, the French Ministry of Education and Research, the French Ministry of Foreign Affairs, the Fondation Singer-Polignac and the Leakey Foundation). We thank R.G. de Souza, an anonymous reviewer and editor S. Salisbury for their constructive comments.

\section{LITERATURE CITED}

Aguilera, O. A., D. Riff, and J. Bocquentin-Villanueva 2006. A new giant Purussaurus (crocodyliformes, alligatoridae) from the upper Miocene Urumaco formation, Venezuela. Journal of Systematic Palaeontology 4:221-232.

Antoine, P.-O. and J.-L. Welcomme. 2000. A new rhinoceros from the lower Miocene of the Bugti Hills, Baluchistan, Pakistan: the oldest elasmotheriine. Palaeontology 43:795-816. Antoine, P. -O., S. M. I. Shah, I. U. Cheema, J. -Y. Crochet, D. de Franceschi, L. Marivaux, G. Métais, and J.-L. Welcomme. 2004. New remains of the baluchithere Paraceratherium bugtiense (Pilgrim, 1910) from the Late/latest Oligocene of the Bugti Hills, Balochistan, Pakistan. Journal of Asian Earth Sciences 24:71-77. 
Antoine, P. -O., J .-L. Welcomme, L. Marivaux, I. Baloch, M. Benammi, and P. Tassy. 2003. First record of Paleogene Elephantoidea (Proboscidea, Mammalia) from the Bugti Hills of Pakistan. Journal of Vertebrate Paleontology 23:977-980.

Antoine, P.-O., K. F. Downing, J.-Y. Crochet, F. Duranthon, L. J. Flynn, L. Marivaux, G. Métais, A. R. Rajpar, and G. Roohi. 2010. A revision of Aceratherium blanfordi Lydekker, 1884 (Mammalia: Rhinocerotidae) from the early Miocene of Pakistan: postcranials as a key. Zoological Journal of the Linnean Society 160:139-194.

Antoine, P. -O., G. Métais, M. J. Orliac, J. -Y. Crochet, L. J. Flynn, L. Marivaux, A. R. Rajpar, G. Roohi, and J.-L. Welcomme. 2013. Mammalian Neogene biostratigraphy of the Sulaiman Province, Pakistan; pp. 400-422 in X. -M. Wang, L. J. Flynn, and M. Fortelius (eds.), Fossil mammals of Asia: Neogene Biostratigraphy and Chronology. Columbia University Press.

Aureliano, T., A. M. Ghilardi, E. Guilherme, J. P. Souza-Filho, M. Cavalcanti, and D. Riff. 2015. Morphometry, bite-force, and paleobiology of the Late Miocene Caiman Purussaurus brasiliensis. PloS one 10:e0117944.

Britton, A., R., Whitaker, and N. Whitaker. 2012. Here be a dragon: exceptional size in a saltwater crocodile (Crocodylus porosus) from the Philippines. Herpetological Review $43: 541-546$.

Brochu, C. A., and G. W. Storrs 2012. A giant crocodile from the Plio-Pleistocene of Kenya, the phylogenetic relationships of Neogene African crocodylines, and the antiquity of Crocodylus in Africa. Journal of Vertebrate Paleontology 32, 587-602.

Buffetaut, E. 1979. Présence du crocodilien Phosphatosaurus (Mesosuchia, Dyrosauridae) dans le paléocène du Niger et du Mali. Paläontologische Zeitschrift 53:323-333.

Da Silva, A., and J. Lenin. 2010. Mugger crocodile Crocodylus palustris. Third Edition. Status survey and conservation action plan. Darwin: Crocodile Specialist Group, 94-98. 
Delfino, M., M. Böhme, and L. Rook. 2007. First European evidence for transcontinental dispersal of Crocodylus (late Neogene of southern Italy). Zoological Journal of the Linnean Society 149:293-307.

Delfino, M., and T. Smith. 2009. A reassessment of the morphology and taxonomic status of 'Crocodylus' depressifrons (Crocodylia, Crocodyloidea) based on the Early Eocene remains from Belgium. Zoological Journal of the Linnean Society 156:140-167.

Delfino, M., and De Vos, J. 2014. A giant crocodile in the Dubois Collection from the Pleistocene of Kali Gedeh (Java). Integrative zoology 9:141-147.

Erickson, G. M., and C. A. Brochu 1999. How the 'terror crocodile grew so big. Nature 398:205.

Fitzinger, L.J. 1826. Neue Classification der Reptilien nach ihren natürlichen Verwandtschaften. Nebsteiner Verwandtschaftstafel und einem Verzeichnisseder Reptiliensammlung des K.K. Zoologischen Museum's zu Wien. Vienna.

Fukuda, Y., K. Saalfeld, G. Lindner, and T. Nichols. 2013. Estimation of total length from head length of saltwater crocodiles (Crocodylus porosus) in the Northern Territory, Australia. Journal of Herpetology 47:34-40.

Gmelin, J. F. 1789. Tom. I. Pars III. Pages 1033-1516 in Caroli a Linné, Systema Naturae (G. E. Beer, ed). Leipzig, Germany.

Head, J. J. 2001. Systematics and body size of the gigantic, enigmatic crocodyloid Rhamphosuchus crassidens, and the faunal history of Siwalik Group (Miocene) crocodylians. Journal of Vertebrate Paleontology 21:A59.

Lihoreau, F., L. Alloing-Séguier, P.-O. Antoine, J.-R. Boisserie, L. Marivaux, G. Métais, and J.-L. Welcomme. 2017. Enamel microstructure defines a major Paleogene hippopotamoid clade: the Merycopotamini (Artiodactyla, Hippopotamoidea). Historical Biology 29:947-957. 
Marivaux, L., J.-L. Welcomme, P.-O. Antoine, G. Métais, I. M. Baloch, M. Benammi, Y. Chaimanee, S. Ducrocq, and J.-J. Jaeger. 2001. A fossil lemur from the Oligocene of Pakistan. Science 294: 587-591.

Marivaux, L., P. -O. Antoine, S. R. H. Baqri, M. Benammi, Y. Chaimanee, J. -Y. Crochet, D. De Franceschi, N. Iqbal, J.-J. Jaeger, G. Métais, G. Roohi, and J.-L. Welcomme. 2005. Anthropoid primates from the Oligocene of Pakistan (Bugti Hills): data on early anthropoid evolution and biogeography. Proceedings of the National Academy of Sciences, USA 102:8436-8441.

Marivaux, L., M. Vianey-Liaud, and J.-L.Welcomme. 1999. Première découverte de Cricetidae (Rodentia, Mammalia) oligocènes dans le synclinal Sud de Gandoï (Bugti Hills, Balouchistan, Pakistan). Comptes rendus de l'Académie des Sciences 329:839_ 844.

Marivaux, L., and J.-L. Welcomme. 2003. Diatomyid and baluchimyine rodents from the Oligocene of Pakistan (Bugti Hills, Balochistan): systematic and paleobiogeographic implications. Journal of Vertebrate Paleontology 23:420-434.

Marivaux, L., J.-L. Welcomme, S. Ducrocq, and J.-J. Jaeger. 2002. Oligocene sivaladapid primate from the Bugti Hills (Balochistan, Pakistan) bridges the gap between Eocene and Miocene adapiform communities in southern Asia. Journal of Human Evolution 42:379388.

Marivaux, L., J.-L. Welcomme, M. Vianey-Liaud, and J.-J. Jaeger. 2002. The role of Asia in the origin and diversification of hystricognathous rodents. Zoologica Scripta 31:225-239.

Martin, J. E., K. Lauprasert, E. Buffetaut, R. Liard, and V. Suteethorn. 2014. A large pholidosaurid in the Phu Kradung Formation of north-eastern Thailand. Palaeontology 57:757-769. 
Martin, J. E. 2018. The taxonomic content of the genus Gavialis from the Siwalik Hills of India and Pakistan. Papers in Palaeontology. doi.org/10.1002/spp2.1247

Martin, J. E., K. Lauprasert, E. Buffetaut, R. Liard, and V. Suteethorn. 2014. A large pholidosaurid in the Phu Kradung Formation of northeastern Thailand. Palaeontology $57: 757-769$.

Martin, J. E., J. Raslan-Loubatié, and J.-M. Mazin. 2016. Cranial anatomy of Pholidosaurus purbeckensis from the Lower Cretaceous of France and its bearing on pholidosaurid affinities. Cretaceous Research 66:43-59.

Métais, G., P.-O. Antoine, S. R. H. Baqri, M. Benammi, J.-Y. Crochet, D. De Franceschi, L. Marivaux, and J.-L. Welcomme. 2006. New remains of the enigmatic cetartiodactyl Bugtitherium grandincisivum Pilgrim 1908, from the upper Oligocene of the Bugti Hills (Balochistan, Pakistan). Naturwissenschaften 93:348-355.

Métais, G., P.-O. Antoine, L. Marivaux, S. Ducrocq, and J.-L. Welcomme. 2003. New artiodactyl ruminant mammal from the late Oligocene of Pakistan. Acta Palaeontologica Polonica 48:375-382.

Métais, G., P. -O. Antoine, S. H. Baqri, J. -Y. Crochet, D. De Franceschi, L. Marivaux, and J. -L. Welcomme. 2009. Lithofacies, depositional environments, regional biostratigraphy and age of the Chitarwata Formation in the Bugti Hills, Balochistan, Pakistan. Journal of Asian Earth Sciences 34:154-167.

Métais, G., J. -L. Welcomme, and S. Ducrocq. 2009. New lophiomerycid ruminants from the Oligocene of the Bugti Hills (Balochistan, Pakistan). Journal of Vertebrate Paleontology 29:231-241.

Métais, G., B., Mennecart, and G. Roohi. 2017. A new assemblage of stem pecoran ruminants from the Oligocene Chitarwata Formation, Bugti Hills, Baluchistan, Pakistan: 
Paleoenvironmental and paleobiogeographic implications. Journal of Asian Earth Sciences 136:40-49.

Njau, J., and R. J. Blumenschine. 2006. A diagnosis of crocodile feeding traces on larger mammal bone, with fossil examples from the Plio-Pleistocene Olduva Basin, Tanzania. Journal of Human Evolution 50:142-162.

Orliac, M. J., P-O, Antoine, G. Métais, J. -Y. Crochet, L. Marivaux, G. Roohi, and J. -L. Welcomme. 2009. Listriodon guptai Pilgrim, 1926 (Mammalia, Suidae) from the early Miocene of the Bugti Hills, Balochistan, Pakistan: new insights into early Listriodontinae evolution and biogeography. Naturwissenschaften 96:911-920.

Orliac, M. J., P.-O. Antoine, G. Roohi, and J.-L. Welcomme. 2010. Suoidea (Mammalia, Cetartiodatyla) from the early Oligocene of the Bugti Hills, Balochistan, Pakistan. Journal of Vertebrate Paleontology 30:1300-1305.

Pilgrim, G. E. 1908. The Tertiary and post-Tertiary freshwater deposits of Baluchistan and Sind with notices of new vertebrates. Records oft he Geological Survey of India 37:139166.

Pilgrim, G. E. 1912. The vertebrate fauna of the Gaj series in the Bugti Hills and the Punjab. Memoirs oft he Geological Survey of India. Palaeontologica Indica New Series 4:1-83. Riff, D., and O. A. Aguilera 2008. The world's largest gharials Gryposuchus: description of G. croizati n. sp. (Crocodylia, Gavialidae) from the Upper Miocene Urumaco Formation, Venezuela. Paläontologische Zeitschrift 82:178-195.

Salas-Gismondi, R., J. J. Flynn, P. Baby, J. Tejada-Lara, F. P. Wesselingh, and P. -O. Antoine 2015. A Miocene hyperdiverse crocodylian community reveals peculiar trophic dynamics in proto-Amazonian mega-wetlands. Proceedings of the Royal Society B 282:20142490. Sereno, P. C., H. C. Larsson, C. A. Sidor,and B. Gado. 2001. The giant crocodyliform Sarcosuchus from the Cretaceous of Africa. Science 294:1516-1519. 
Souza, R. G., G. M. Cidade, D. De. A. Campos, and D. Riff. 2016. New crocodilian remains from the Solimões Formation (lower Eocene-Pliocene), state of Acre, Southwestern Brazilian Amazonia. Revista Brasileira de Paleontologia 19:217-232.

Stromer, E. 1925. Ergebnisse der Forschungsreisen Prof. E. Stromers in den Wüsten

Ägyptens. II. Wirbeltier-Reste der Baharije-Stufe (unterstes Cenoman). 7. Stomatosuchus inermis Stromer, ein schwach bezahnter Krokodilier und 8. Ein Skelettrest des Pristiden Onchopristis numidus Haug sp. Abhandlungen der Bayerischen Akademie der Wissenschaften, Mathematisch-naturwissenschaftliche Abteilung 30:1-22.

Vickary, N. 1846. Geological report on a portion of the Beloochistan Hills. The Quaterly Journal of the Geological Society of London 2:260-266.

Welcomme, J. L., P. -O. Antoine, F. Duranthon, P. Mein, and L. Ginsburg. 1997. Nouvelles découvertes de Vertébrés miocènes dans le synclinal de Dera Bugti (Balouchistan, Pakistan). Comptes Rendus de l'Académie des Sciences-Series IIA-Earth and Planetary Science 325:531-536.

Welcomme, J.-L., and L. Ginsburg. 1997. Mise en évidence de l'Oligocène sur le territoire des Bugti (Balouchistan, Pakistan). Comptes Rendus de l'Académie des Sciences-Series IIAEarth and Planetary Science 325:999-1004.

Welcomme, J. L., M. Benammi, J. Y. Crochet, L. Marivaux, G. Métais, P. O. Antoine, and I. Baloch. 2001. Himalayan Forelands: palaeontological evidence for Oligocene detrital deposits in the Bugti Hills (Balochistan, Pakistan). Geological Magazine 138:397-405. Submitted January 22, 2019; accepted Month DD, YYYY.

\section{Figure captions}

FIGURE 1. Holotype specimen (IM E221) of Astorgosuchus bugtiensis comb. nov., modified after plates XXVI and XXVII in Pilgrim (1912), Oligocene, Pishi Nala, Bugti Hills, Pakistan 
in $\mathbf{A}$, dorsal view and $\mathbf{B}$, ventral view. Abbreviations: en, external nares; lp, lacrimal prominence; mx, maxilla; np, nasal prominence; op, occlusal pit; pmx, premaxilla; pmxp, premaxillary prominence; sof, suborbital fenestra. Numerals refer to maxillary alveolar count. [Intended for page width]

FIGURE 2. Photographs and associated drawings of the mandibular rostrum of Astorgosuchus bugtiensis comb. nov. (UM-DB-LCJ1-02) from the upper Oligocene of the Bugti Hills, Pakistan in A, B, occlusal and C, D, ventral views. Abbreviations: den, dentary; fo, foramen; sp, splenial; numerals denote alveolar count. [Intended for page width]

FIGURE 3. Photographs and associated drawings of the mandibular rostrum of Astorgosuchus bugtiensis comb. nov. (UM-DB-LCJ1-02) from the upper Oligocene of the Bugti Hills, Pakistan in A, B, right lateral; C, D, anterior and E, F, posterior views. Abbreviations: fo, foramen; sp, splenial; numbers denote alveolar count. [Intended for page width]

FIGURE 4. Photographs of the partial mandibular rostrum of Astorgosuchus bugtiensis comb. nov. (NHMUK R.5266) from the Oligocene of the Bugti Hills, Pakistan in A, occlusal; B, left lateral and $\mathbf{C}$, ventral views. Abbreviations: op, occlusal pit; sp, splenial; numbers denote alveolar count. [Intended for half a page width]

FIGURE 5. Selected perissodactyl specimens from the upper Oligocene-lower Miocene deposits of the Bugti Hills, Pakistan, presenting toothmarks attributable to large crocodylomorphs. A, cf. Rhinoceros sp. (MNHN-Pak 2221 field-number), distal fragment of a left ulna, in anterior view (DB6 locality, early Miocene). B, Paraceratherium bugtiense, 
juvenile jaw, in lingual view (Lundo Chur J2 locality, upper Oligocene). C, Chalicotheriidae indet. (MNHN-Pak 1715), fragmentary right tibia, in posterior view (Kumbi 4F locality, earliest Miocene). Black arrows denote crocodylomorph toothmarks. [Intended for page width] 

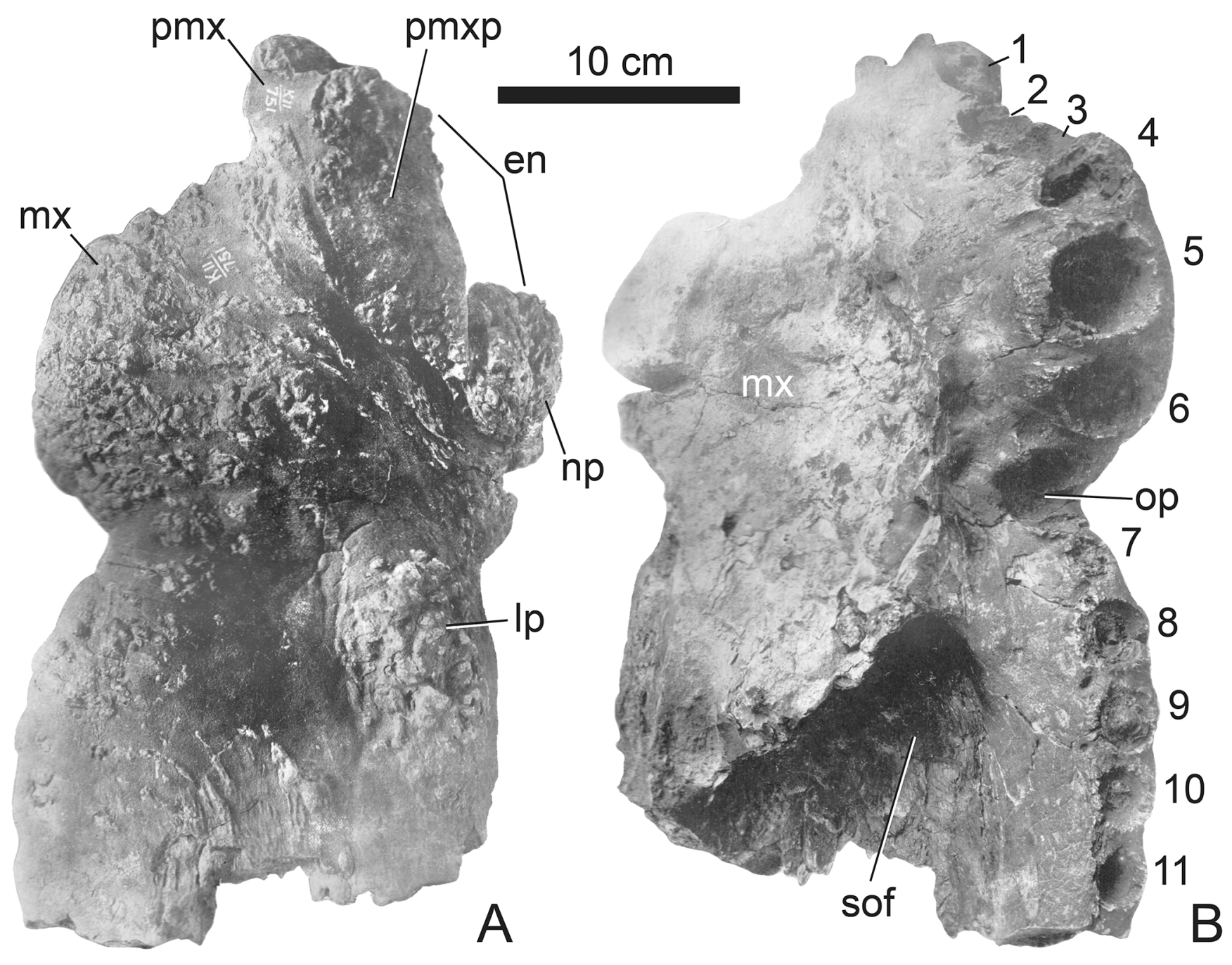


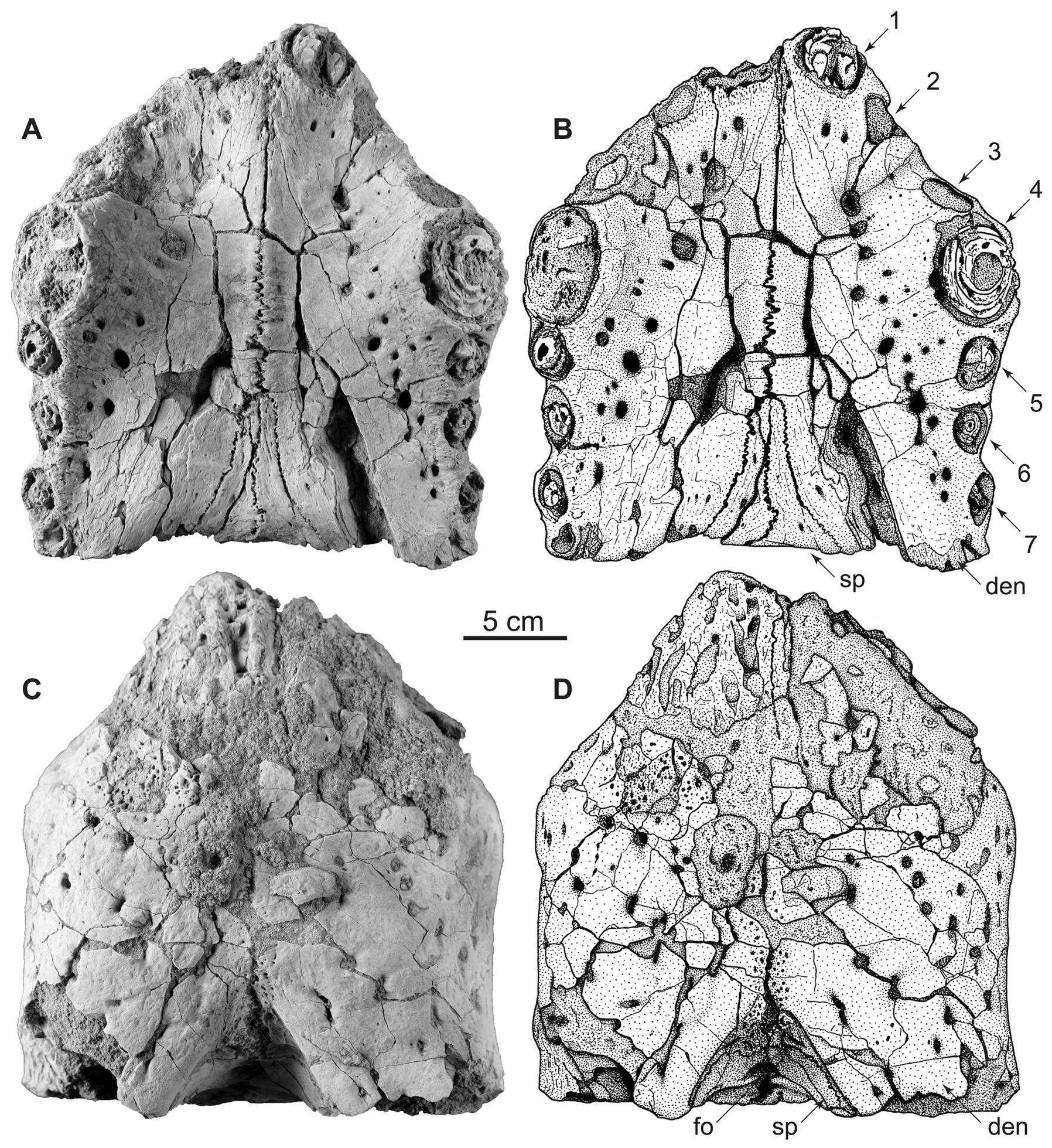




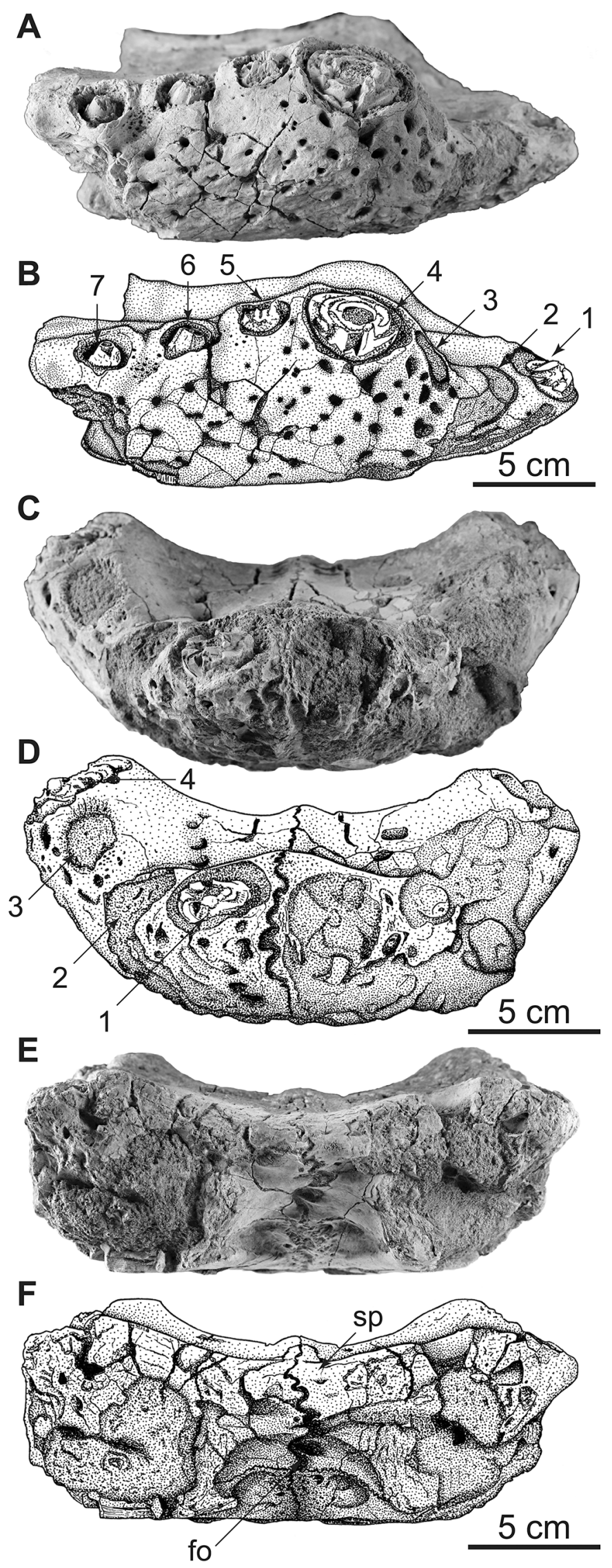




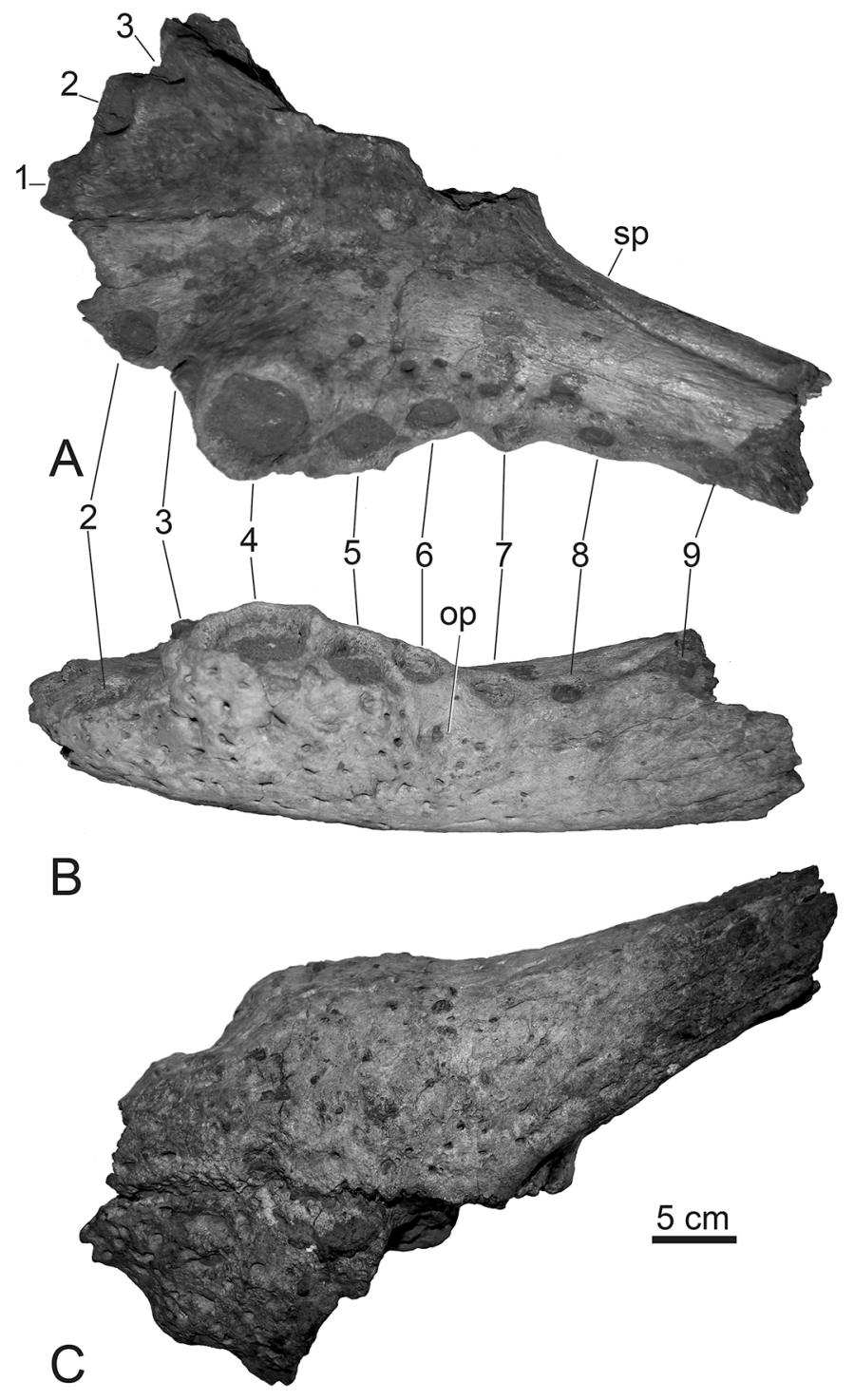



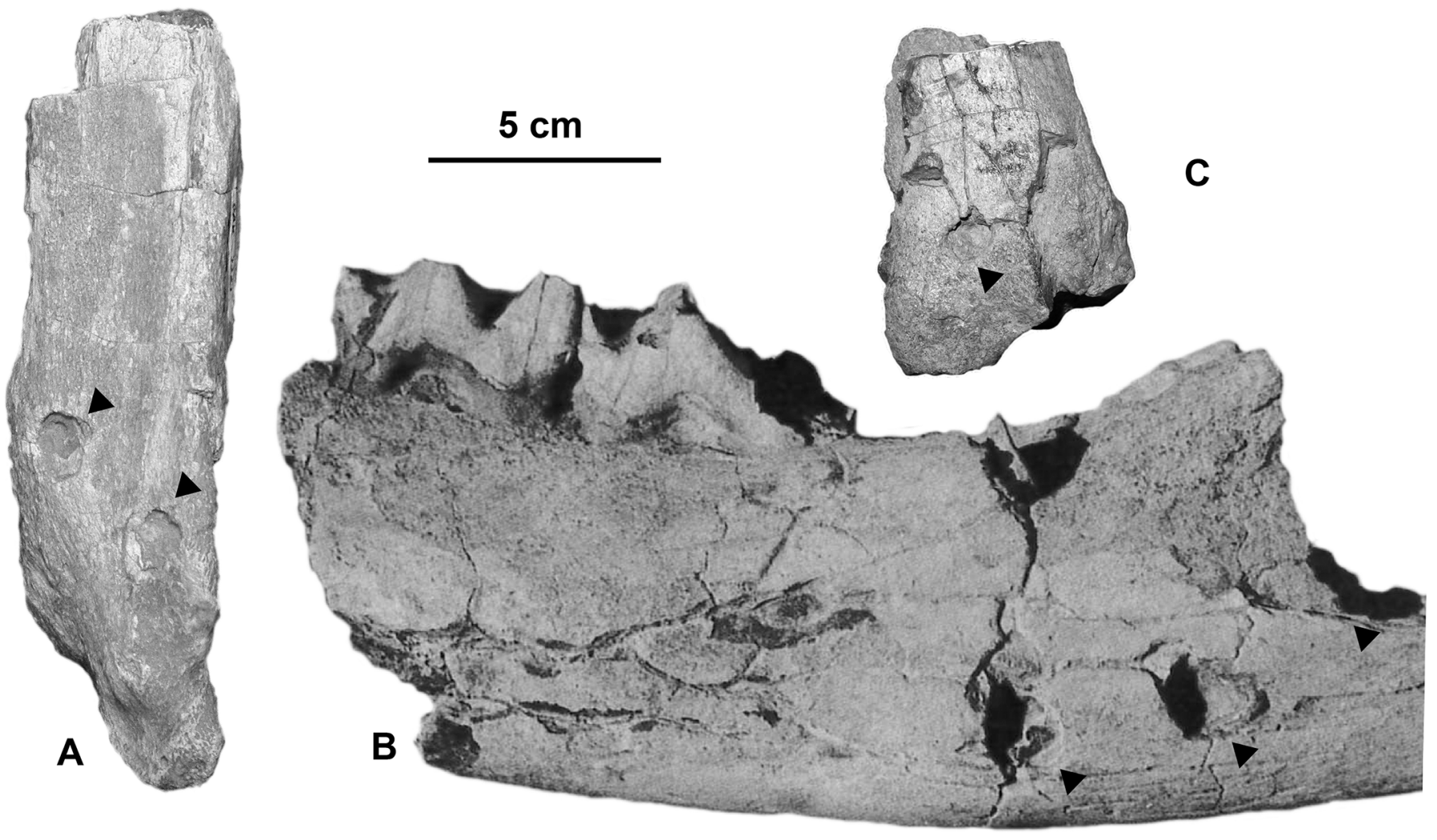


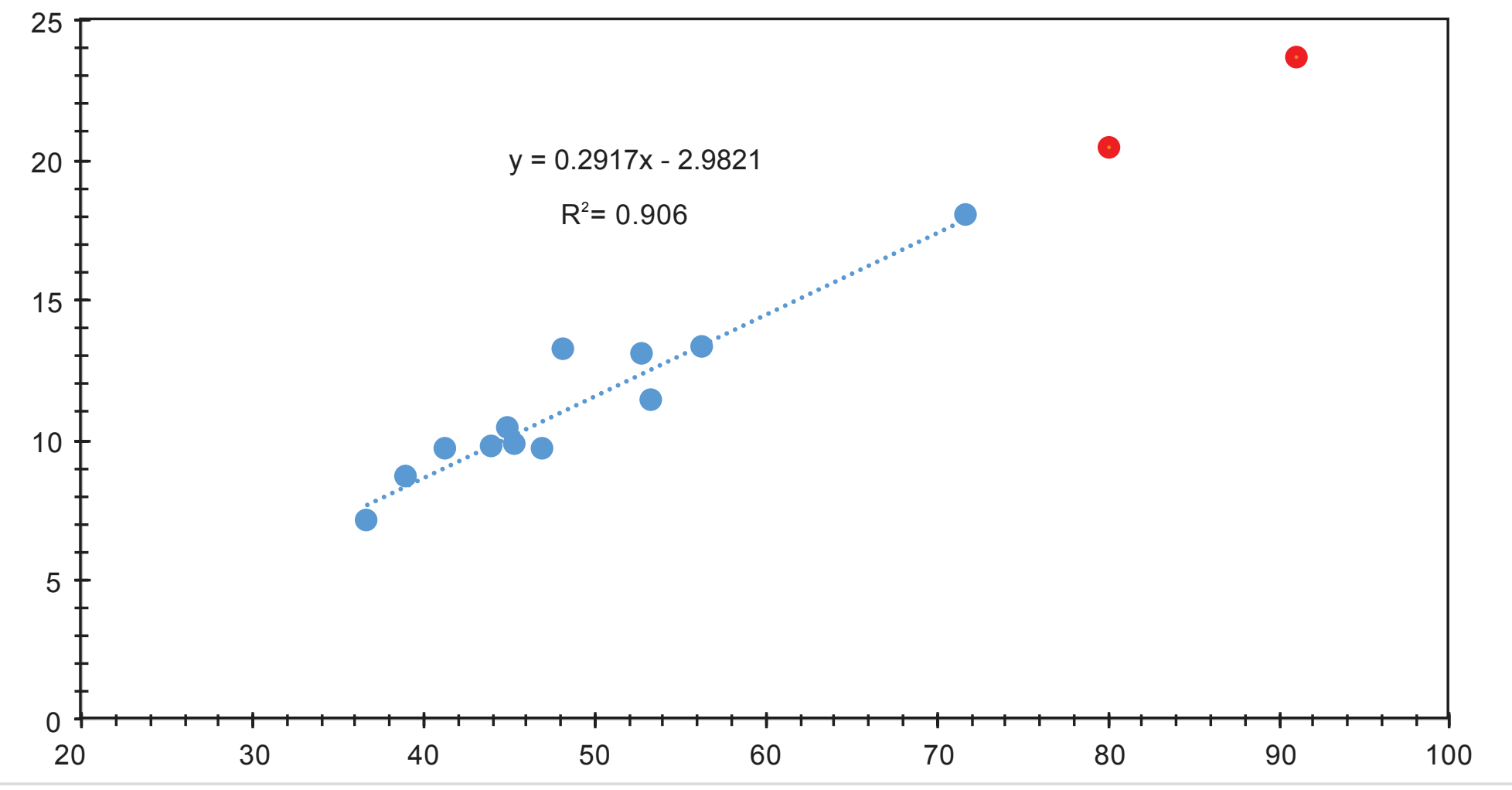

FIGURE S1. Regression lined obtained for skull length versus dentary width (in $\mathrm{cm}$ ) of modern specimens of Crocodylus (blue dots). The equation is used to infer skull dimensions of the two mandibles of Astorgosuchus bugtiensis (red dots) described in this work (see Table 2 for measurements). 
TABLE 1. Alveolar dimensions (in mm) of the dentary Astorgosuchus bugtiensis (UM-DB-LCJ1-02). Abbreviations: ${ }^{\text {a }}$, mesiodistal length; ${ }^{\mathrm{b}}$, labiolingual length; ${ }^{\mathrm{d}}$, damaged alveolar border.

Dentary $\quad$ left $^{\mathrm{a}} \quad$ left $^{\mathrm{b}} \quad$ right $^{\mathrm{a}} \quad$ right $^{\mathrm{b}}$ alveolus

\begin{tabular}{lllll}
\hline$\# 1$ & $34^{\mathrm{d}}$ & $33^{\mathrm{d}}$ & 33 & 30 \\
$\# 2$ & 22 & 21 & $24^{\mathrm{d}}$ & $?$ \\
$\# 3$ & $?$ & $?$ & 25 & 23 \\
$\# 4$ & 46 & 42 & 44 & 44 \\
$\# 5$ & 24 & 23 & 23 & 20 \\
$\# 6$ & 23 & 20 & 22 & 17 \\
$\# 7$ & 23 & 20 & 19 & 19
\end{tabular}


TABLE 2. Maximum TBL of crocodylomorphs surpassing 7 meters stratigraphically sorted from oldest to youngest.

\begin{tabular}{llll} 
Age & Taxon & estimated TBL & Reference \\
\hline Early Cretaceous & Chalawan thailandicus & $7-8 \mathrm{~m}$ & Martin et al. 2014 \\
Aptian-Albian & Sarcosuchus imperator & $11-12 \mathrm{~m}$ & Sereno et al. 2001 \\
Cenomanian & Stomatosuchus inermis & $10 \mathrm{~m}$ & Stromer, 1925 \\
Campanian & Deinosuchus sp. & $9.1 \mathrm{~m}$ & Erickson and Brochu, 1999 \\
early Eocene & Phosphatosaurus gavialoides & $9 \mathrm{~m}$ & Buffetaut, 1979 \\
late Oligocene & Astorgosuchus bugtiensis & $8 \mathrm{~m}$ & this study \\
late Miocene & Mourasuchus mirandai & $11.5 \mathrm{~m}$ & Aguilera et al. 2006 \\
Miocene & Purussaurus brasiliensis & $12.5 \mathrm{~m}$ & Aureliano et al. 2015 \\
Mio-Pliocene & Gryposuchus croizati & $10.15 \mathrm{~m}$ & Riff and Aguilera, 2008 \\
Mio-Pliocene & Rhamphosuchus crassidens & $8-11 \mathrm{~m}$ & Head, 2001 \\
Pleistocene & Crocodylus thorbjarnarsoni & $7.6 \mathrm{~m}$ & Brochu and Storrs, 2012 \\
Pleistocene & Kali Gedeh Crocodylus & $7 \mathrm{~m}$ & Delfino and De Vos, 2013
\end{tabular}

